\title{
EVALUASI KINERJA TEKNIS PDAM TIRTA KEPRI PROVINSI KEPULAUAN RIAU
}

\author{
Ida Munfarida \\ Program Studi Teknik Lingkungan, Fakultas Sains dan Teknologi, UIN Sunan Ampel Surabaya \\ Email: munfarida@uinsby.ac.id
}

\begin{abstract}
ABSTRAK
Penilaian kinerja aspek pelayanan PDAM terdiri dari aspek teknis, keuangan dan manajemen. Evaluasi kinerja pelayanan PDAM bertujuan untuk mendapatkan gambaran dan penilaian terhadap pelayanan PDAM sehingga dapat merumuskan rencana tindak pelayanan PDAM. Dalam penelitian ini, evaluasi kinerja difokuskan pada kinerja teknis PDAM Tirta Kepri Kota Tanjungpinang Provinsi Kepulauan Riau yang terdiri dari 6 indikator kinerja teknis antara lain: pertumbuhan pelanggan, persentase pelayanan, volume produksi air, volume distribusi air, volume penjualan air, dan kehilangan air PDAM Tirta Kepri selama rentang waktu 3 tahun dari tahun 2012 hingga tahun 2015. Penelitian berdasarkan data sekunder Laporan Teknik PDAM Tirta Kepri tahun 2016 dan audit BPKP PDAM Tirta Kepri Kota Tanjungpinang tahun 2012-2014. Kinerja pelayanan teknis PDAM Tirta Kepri untuk kategori jumlah pelanggan dan tingkat kebocoran mengalami peningkatan dari tahun 2012 hingga tahun 2015, namun volume produksi, distribusi dan penjualan mengalami penurunan dan prosentase pelayanan belum memenuhi target nasional, dimana jumlah pelanggan tahun 2012 sebesar 14.769 SR meningkat menjadi 5.306 SR di tahun 2015 sementara prosentase pelayanan pada tahun 2015 sebesar $30 \%$ tidak menunjukkan peningkatan dari tahun 2012. Rencana tindak dalam peningkatan pelayanan PDAM Tirta Kepri meliputi peningkatan sambungan rumah, meningkatkan produksi dan distribusi air melalui optimalisasi IPA, meningkatkan penjualan air dan non air, dan menekan kebocoran.
\end{abstract}

Kata kunci: PDAM Tirta Kepri, Kinerja Teknis, Pelayanan

\section{PENDAHULUAN}

\section{Latar Belakang Masalah}

Air merupakan salah satu kebutuhan dasar bagi kualitas dan keberlanjutan kehidupan manusia. Oleh karenanya air bersih mutlak harus tersedia dalam kuantitas dan kualitas yang memadai. Sektor air minum merupakan aspek pembangunan yang memiliki fungsi penting dalam menunjang tingkat kesejahteraan masyarakat, karena berkaitan dengan kesehatan, pola hidup, kondisi lingkungan permukiman serta kenyamanan dalam kehidupan sehari-hari. Pelayanan air minum yang baik tentunya akan memberikan dampak pada perbaikan sosial, ekonomi dan lingkungan. Mengacu pada PP Nomor 122 Tahun 2015, maka sistem penyediaan air minum disebut sebagai SPAM.

Pengembangan SPAM adalah kegiatan yang bertujuan membangun, memperluas dan/atau meningkatkan sistem fisik (teknik) dan non fisik (kelembagaan, manajemen, keuangan, peran serta masyarakat, dan hukum) dalam kesatuan yang utuh untuk melaksanakan penyediaan air minum kepada masyarakat menuju keadaan yang lebih baik (PP Nomor 122 Tahun 2015). Di dalam pelaksanaannya, pengembangan SPAM dilakukan oleh penyelenggara SPAM yang salah satunya adalah PDAM yang merupakan badan usaha milik daerah, yaitu badan usaha yang pendiriannya diprakarsai oleh pemerintah daerah dan seluruh atau sebagian besar modalnya dimiliki oleh daerah melalui penyertaan secara langsung yang berasal dari kekayaan daerah yang dipisahkan yang dibentuk khusus sebagai Penyelenggara (PP Nomor 122 Tahun 2015).

Pengelolaan SPAM oleh PDAM perlu dipantau dan dievaluasi melalui suatu ukuran tingkat keberhasilan pengelolaan terutama dalam hal capaian pelayanan air minum kepada masyarakat. 
Penilaian kinerja aspek pelayanan bertujuan untuk mengukur beberapa perspektif pelayanan yang menggambarkan tingkat kemampuan PDAM memenuhi kebutuhan pelanggannya. Perspektif yang tercakup diantaranya: kualitas, kuantitas, kontinuitas, kepuasan pelanggan, kemampuan nyata pelayanan, dan pertumbuhan pelanggan.

Berdasarkan perspektif tersebut, maka disimpulkan bahwa terdapat 5 (lima) indikator yang diperkirakan dapat mewakili perspektif pelayanan seperti dimaksud, yaitu: Cakupan Pelayanan Teknis, Pertumbuhan Pelanggan, Tingkat Penyelesaian Pengaduan, Kualitas Air Pelanggan, dan Konsumsi Air Domestik. Metode ini disebut Balanced Scorecard (Kaplan, et.al, 2000).

Dari aspek kinerja teknis dapat dikategorikan menjadi 6 indikator antara lain : pertumbuhan pelanggan, persentase pelayanan, volume produksi air, volume distribusi air, penjualan air, dan kehilangan air. Sehingga fokus penelitian pada 6 indikator kinerja teknis tersebut.

Provinsi Kepulauan Riau merupakan salah satu provinsi bahari di Republik Indonesia. Provinsi Kepulauan Riau dikelilingi laut dan daratannya terdiri dari banyak gugusan pulau. Ketersediaan air minum menjadi sangat penting karena sumber air yang utama adalah laut sehingga keberadaan PDAM menjadi sangat penting di Pulau ini.

PDAM Tirta Kepri adalah Perusahaan Daerah Air Minum Provinsi Kepulauan Riau yang melayani Kota Tanjungpinang dan sebagian Kabupaten Bintan Provinsi Kepulauan Riau. Saat ini PDAM Tirta Kepri telah melayani beberapa jenis pelayanan seperti rumah tangga dan jenis peleyanan Non Domestik seperti sosial umum, sosial khusus, instansi pemerintah, niaga (besar dan kecil), industri dan golongan khusus atau bandara. Dalam penelitian ini penulis mengambil data laporan teknik PDAM Tirta Kepri Tahun 2016 sebagai obyek penelitian mengenai Kinerja Pelayanan PDAM Tirta Kepri ditinjau dari 6 indikator tersebut. Kondisi geografis Kota Tanjungpinang dan Kabupaten Bintan terlihat pada Gambar 1.

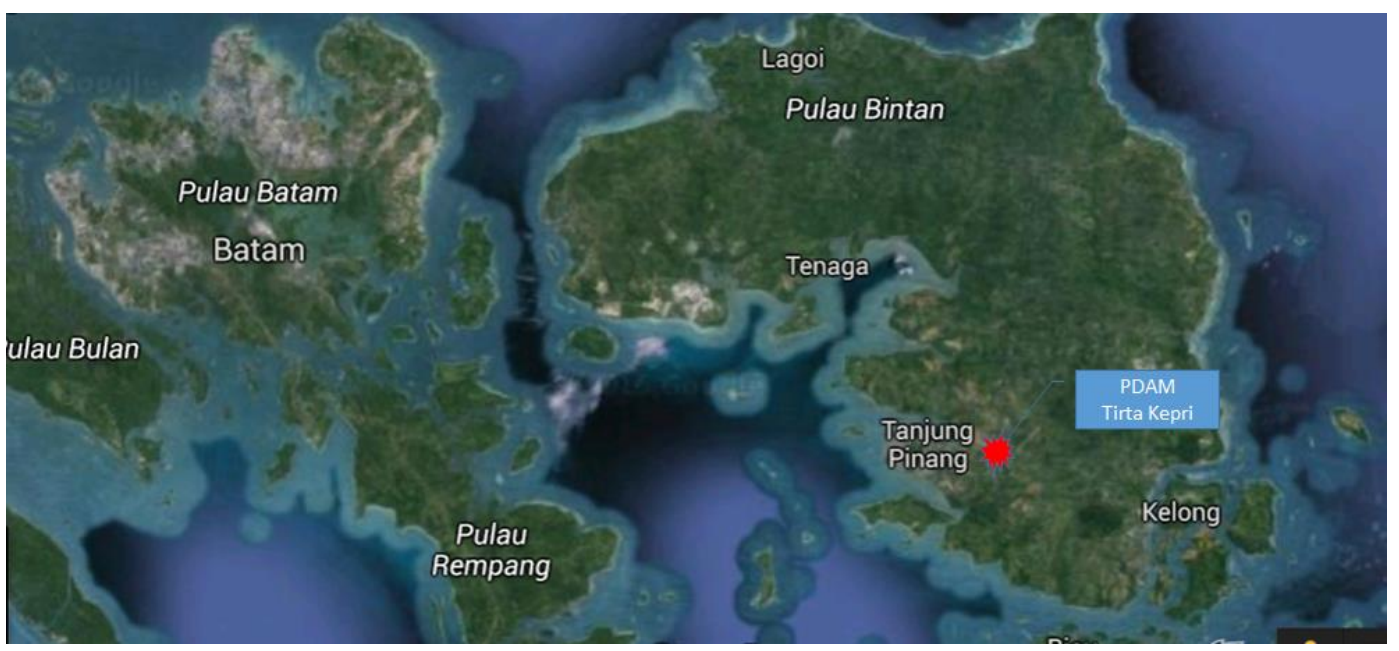

Gambar 1. Kota Tanjungpinang dan Kab. Bintan

\section{Tujuan Penelitian}

Maksud dari disusunnya evaluasi kinerja teknis pelayanan PDAM Tirta Kepri Provinsi Kepulauan Riau adalah agar

diperoleh penilaian kinerja Pelayanan teknis PDAM Tirta Kepri.

Adapun tujuannya adalah:

1. Memperoleh hasil penilaian kinerja teknis pelayanan PDAM Tirta Kepri ditinjau dari 6 indikator pelayanan teknis;

2. Memperoleh perumusan rencana tindak peningkatan kinerja pelayanan PDAM Tirta Kepri.

\section{Lokasi dan waktu penelitian}

Penelitian dilakukan berdasarkan data sekunder yaitu data Laporan Teknik PDAM Tirta Kepri Tahun 2016. 


\section{METODOLOGI PENELITIAN}

Metodologi yang digunakan dalam pelaksanaan penelitian ini adalah analisa kinerja pelayanan teknis dari 6 indikator kinerja teknis. Adapun data diperoleh dari data sekunder. Data sekunder diperoleh dari PDAM berupa data Laporan Teknik PDAM Tirta Kepri tahun 2016 dan Laporan Audit BPKP PDAM Tirta Kepri Kota Tanjungpinang tahun 2012-2014.

\section{HASIL DAN PEMBAHASAN}

\section{Analisis Kinerja Pelayanan PDAM}

Tingkat keberhasilan pengelolaan PDAM ini diukur melalui proses penilaian terhadap kinerja PDAM yang didasarkan pada indikator kinerja penyelenggaraan pengembangan SPAM meliputi: aspek keuangan, operasional, pelayanan pelanggan dan sumber daya manusia sesuai dengan ketentuan di dalam Pasal 59 Permen PU No. 18/PRT/M/2007. Dalam penelitian ini, penulis memfokuskan pada kinerja pelayanan tenknis PDAM melalui 6 indikator kinerja teknis antara lain : pertumbuhan pelanggan, persentase pelayanan, volume produksi air, volume distribusi air, penjualan air, dan kehilangan air.

Unit Pelayanan PDAM Tirta Kepri

Unit Pelayanan PDAM Tirta Kepri terdiri dari 4 (empat) unit IPA dengan kapasitas terpasang 275 L/dt.

Tabel 1. Kapasitas Terpasang IPA PDAM Tirta Kepri

\begin{tabular}{cccccc} 
NO. & & IPA & TAHUN & \multicolumn{2}{c}{ KAP. TERPASANG } \\
\cline { 4 - 5 } & & DIBANGUN & $(\mathrm{lt} / \mathrm{dt})$ & $(\mathrm{m} 3 / \mathrm{th})$ \\
\hline & & & & \\
1 & PCM & 1971 & 70 & 2.177 .280 \\
2 & WK & 1980 & 65 & 2.021 .760 \\
3 & PSAB & 1996 & 40 & 1.244 .160 \\
4 & RPD & 1996 & 100 & 3.110 .400 \\
& & & 275 & 8.553 .600 \\
\hline
\end{tabular}

Sumber: Laporan PDAM Tirta Kepri, 2016

Indikator Kinerja Teknis:

1. Pertumbuhan Pelanggan

Berikut adalah profil jumlah pelanggan PDAM Tirta Kepri dari tahun 2015 dilihat dari golongan pelanggan.

Tabel 2. Jumlah Pelanggan PDAM Tirta Kepri Tahun 2015

\begin{tabular}{|c|c|c|c|c|c|c|c|c|c|c|}
\hline & & \multicolumn{9}{|c|}{ TAHUN 2015} \\
\hline NO. & BULAN & SOSIAL & SOSIAL & RUMAH & INSTANSI & NIAGA & NIAGA & INDUS & GOL. & \\
\hline & & UMUM & KHUSUS & TANGGA & PEMERINTAH & KECIL & BESAR & TRI & KHUSUS & JUMLAH \\
\hline 1 & JAN & 39 & 154 & 10.950 & 141 & 3.725 & 213 & 5 & 4 & 15.231 \\
\hline 2 & FEB & 39 & 154 & 10.962 & 143 & 3.751 & 213 & 5 & 4 & 15.271 \\
\hline 3 & MAR & 39 & 157 & 10.981 & 141 & 3.756 & 215 & 5 & 4 & 15.298 \\
\hline 4 & APR & 39 & 160 & 11.020 & 141 & 3.771 & 216 & 5 & 4 & 15.356 \\
\hline 5 & MEI & 39 & 160 & 11.014 & 143 & 3.779 & 214 & 5 & 4 & 15.358 \\
\hline 6 & JUN & 40 & 160 & 11.021 & 144 & 3.771 & 214 & 5 & 4 & 15.359 \\
\hline 7 & JUL & 40 & 162 & 11.025 & 144 & 3.782 & 213 & 5 & 4 & 15.375 \\
\hline 8 & AGT & 40 & & 11.018 & 141 & & 212 & & 4 & 15.362 \\
\hline
\end{tabular}

AL-ARD : JURNAL TEKNIK LINGKUINGAN 


\begin{tabular}{|c|c|c|c|c|c|c|c|c|c|c|}
\hline \multirow[b]{2}{*}{ NO. } & \multirow[b]{2}{*}{ BULAN } & \multicolumn{9}{|c|}{ TAHUN 2015} \\
\hline & & SOSIAL & SOSIAL & RUMAH & INSTANSI & NIAGA & NIAGA & INDUS & GOL. & \\
\hline & & UMUM & KHUSUS & TANGGA & PEMERINTAH & KECIL & BESAR & TRI & KHUSUS & JUMLAH \\
\hline & & & 161 & & & 3.781 & & 5 & & \\
\hline 9 & SEPT & 40 & 162 & 11.016 & 141 & 3.784 & 213 & 5 & 4 & 15.365 \\
\hline 10 & OKT & 40 & 162 & 11.003 & 141 & 3.780 & 215 & 5 & 4 & 15.350 \\
\hline 11 & $\mathrm{NOV}$ & 40 & 162 & 10.966 & 142 & 3.772 & 215 & 5 & 4 & 15.306 \\
\hline 12 & DES & 40 & 162 & 10.976 & 142 & 3.762 & 215 & 5 & 4 & 15.306 \\
\hline
\end{tabular}

Sumber: Laporan PDAM Tirta Kepri, 2016

Dari tahun 2012 hingga tahun 2015 mengalami peningkatan jumlah pelanggan. Profil jumlah pelanggan terlihat pada gambar berikut:

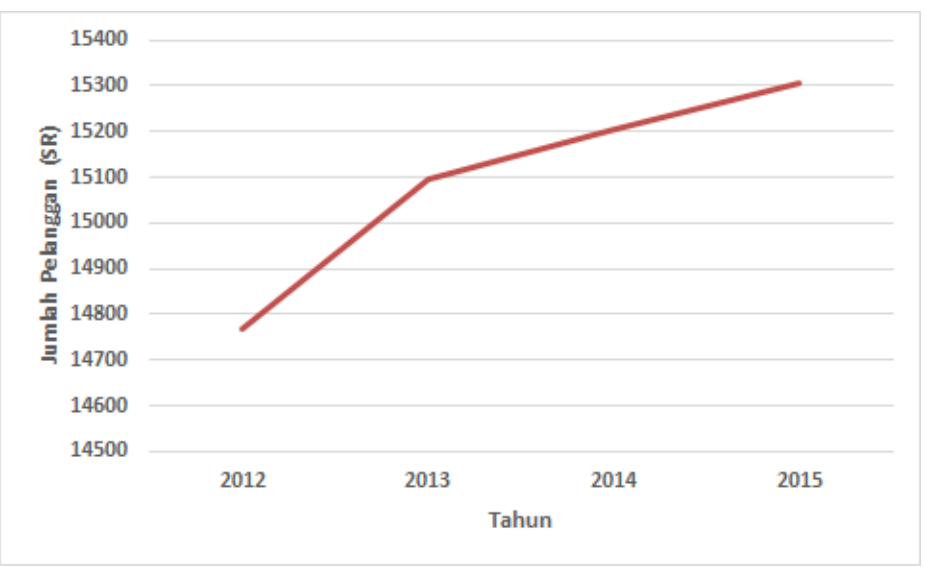

Gambar 2. Profil Jumlah Pelanggan PDAM Tirta Kepri Tahun 2012-2015 (sumber: Laporan Teknik PDAM Tirta Kepri, 2016)

2. Persentase Pelayanan

Hingga tahun 2015, persentase pelayanan PDAM Tirta Kepri baru mencapai 30\% dari total jumlah penduduk Kota Tanjungpinang. Berikut adalah profil persentase pelayanan PDAM Tirta Kepri.

Tabel 3. Persentase Pelayanan PDAM Tirta Kepri

\begin{tabular}{|r|c|c|r|r|}
\hline Tahun & $\begin{array}{c}\text { Jumlah } \\
\text { Pelanggan } \\
\text { (SR) }\end{array}$ & $\begin{array}{c}\text { Jumlah } \\
\text { Penduduk } \\
\text { (Jiwa) }\end{array}$ & $\begin{array}{c}\text { Jml } \\
\text { Pelayanan } \\
\text { Pnddk (Jiwa) }\end{array}$ & \multicolumn{2}{|c|}{$\begin{array}{c}\text { Persentase } \\
\text { Pelayanan } \\
\text { (\%) }\end{array}$} \\
\hline 2012 & 14769 & 194.099 & 59.076 & 30 \\
\hline 2013 & 15095 & 196.980 & 60.380 & 31 \\
\hline 2014 & 15204 & 199.723 & 60.816 & 30 \\
\hline 2015 & 15306 & 202.215 & 61.224 & 30 \\
\hline
\end{tabular}

Sumber: Laporan PDAM Tirta Kepri, 2016 


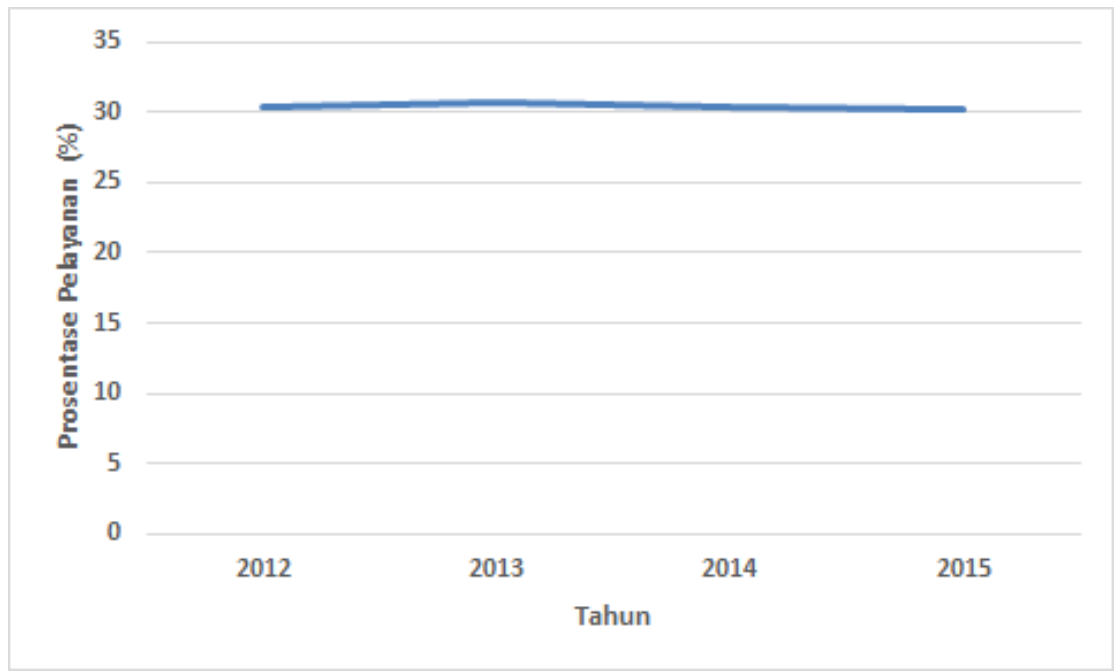

Gambar 3. Persentase Layanan PDAM Tirta Kepri Tahun 2012-2015

3. Volume Produksi Air

Volume produksi air mengalami penurunan dari tahun 2012 hingga tahun 2015 dan nilai ini fluktuatif setiap bulan dan setiap tahunnya. Berikut adalah profil volume produksi air PDAM Tirta Kepri tahun 20122015.

Tabel 4. Volume Produksi PDAM Tirta Kepri Tahun 2012-2015 ( $\left.\mathrm{m}^{3}\right)$

\begin{tabular}{|c|c|c|c|c|c|c|c|c|c|c|c|c|}
\hline PRODUKSI & JAN & FEB & MAR & APR & MEI & JUN & JUL & AGUST & SEPT & OKT & NOV & DES \\
\hline 2012 & 483.056 & 505.680 & 455.551 & 537.595 & 565.296 & 543.437 & 544.264 & 553.877 & 528.683 & 484.464 & 511.593 & 473.108 \\
\hline 2013 & 504.522 & 513.100 & 524.219 & 509.119 & 560.593 & 527.052 & 525.506 & 503.749 & 494.984 & 443.439 & 436.124 & 470.258 \\
\hline 2014 & 485.546 & 490.245 & 493.131 & 467.942 & 398.286 & 424.904 & 449.329 & 461.236 & 425.985 & 426.553 & 461.779 & 345.578 \\
\hline 2015 & 468.671 & 512.255 & 409.516 & 493.404 & 460.389 & 465.179 & 521.659 & 470.821 & 395.682 & 385.865 & & \\
\hline
\end{tabular}

Sumber: Laporan PDAM Tirta Kepri, 2016

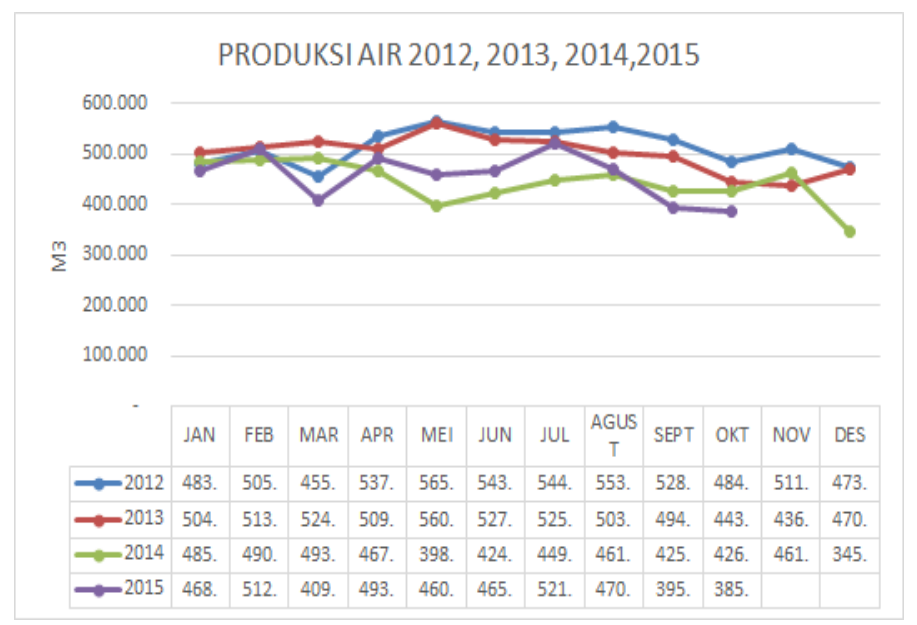

Gambar 4. Profil Produksi Air PDAM Tirta Kepri Tahun 2012-2015 
4. Volume Distribusi Air PDAM Tirta Kepri

Volume distribusi air mengalami penurunan dari tahun 2012 hingga tahun 2015 dan nilai ini fluktuatif setiap bulan dan setiap tahunnya. Berikut adalah profil volume distribusi air PDAM Tirta Kepri tahun 2012-2015.

Tabel 5. Volume Distribusi PDAM Tirta Kepri Tahun 2012-2015 (m³)

\begin{tabular}{|c|c|c|c|c|c|c|c|c|c|c|c|c|}
\hline $\begin{array}{c}\text { DISTRI } \\
\text { BUSI }\end{array}$ & JAN & FEB & MAR & APR & MEI & JUN & JUL & AGUST & SEPT & OKT & NOV & DES \\
\hline 2012 & 476.856 & 499.948 & 450.387 & 532.430 & 549.656 & 502.710 & 537.666 & 549.456 & 520.899 & 476.825 & 503.025 & 464.527 \\
\hline 2013 & 495.000 & 506.800 & 515.202 & 497.473 & 502.769 & 492.892 & 505.443 & 479.328 & 458.161 & 412.279 & 407.567 & 450.605 \\
\hline 2014 & 473.129 & 457.516 & 461.378 & 464.163 & 395.993 & 401.941 & 407.639 & 442.625 & 407.751 & 419.903 & 449.174 & 340.163 \\
\hline 2015 & 460.986 & 493.650 & 398.870 & 484.726 & 446.648 & 448.070 & 490.043 & 456.609 & 382.758 & 374.444 & & \\
\hline
\end{tabular}

Sumber: Laporan PDAM Tirta Kepri, 2016

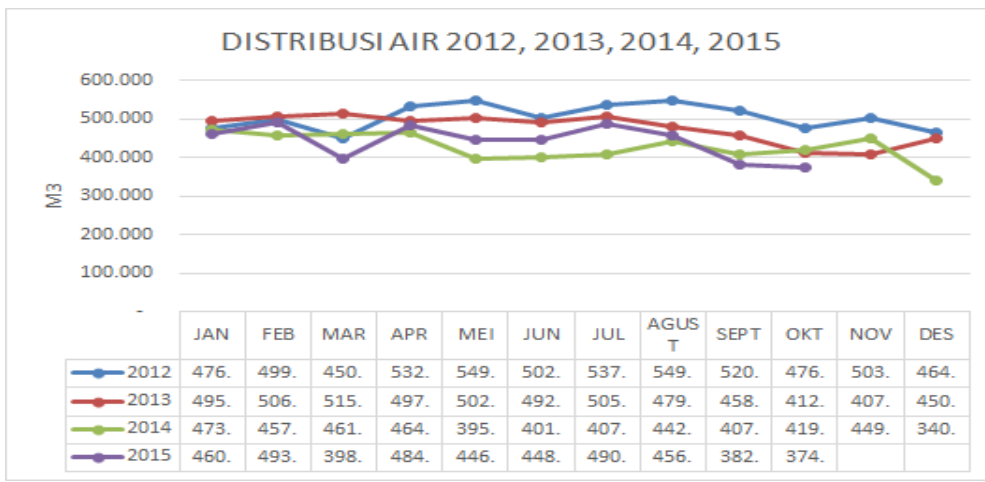

Gambar 5. Profil Distribusi Air PDAM Tirta Kepri Tahun 2012-2015

5. Volume Penjualan Air

Volume penjualan air mengalami penurunan dari tahun 2012 hingga tahun 2015 dan nilai ini fluktuatif setiap bulan dan setiap tahunnya. Nilai penjualan ini lebih rendah dari volume distribusi air. Berikut adalah profil volume penjualan air PDAM Tirta Kepri tahun 2012-2015.

Tabel 6. Penjualan Air PDAM Tirta Kepri Tahun 2012-2015 $\left(\mathrm{m}^{3}\right)$

\begin{tabular}{|c|c|c|c|c|c|c|c|c|c|c|c|c|}
\hline $\begin{array}{c}\text { PENJUALAN } \\
\text { AIR }\end{array}$ & JAN & FEB & MAR & APR & MEI & JUN & JUL & AGUST & SEPT & OKT & NOV & DES \\
\hline 2012 & 164.506 & 248.274 & 222.083 & 182.595 & 160.931 & 168.563 & 163.490 & 184.290 & 161.538 & 170.461 & 144.639 & 231.502 \\
\hline 2014 & 240.569 & 243.922 & 240.823 & 248.802 & 213.447 & 217.214 & 218.441 & 284.907 & 226.615 & 206.717 & 247.877 & 230.515 \\
\hline 2015 & 245.238 & 259.392 & 248.011 & 272.625 & 258.040 & 257.173 & 275.907 & 268.219 & 217.110 & 227.264 & & \\
\hline
\end{tabular}




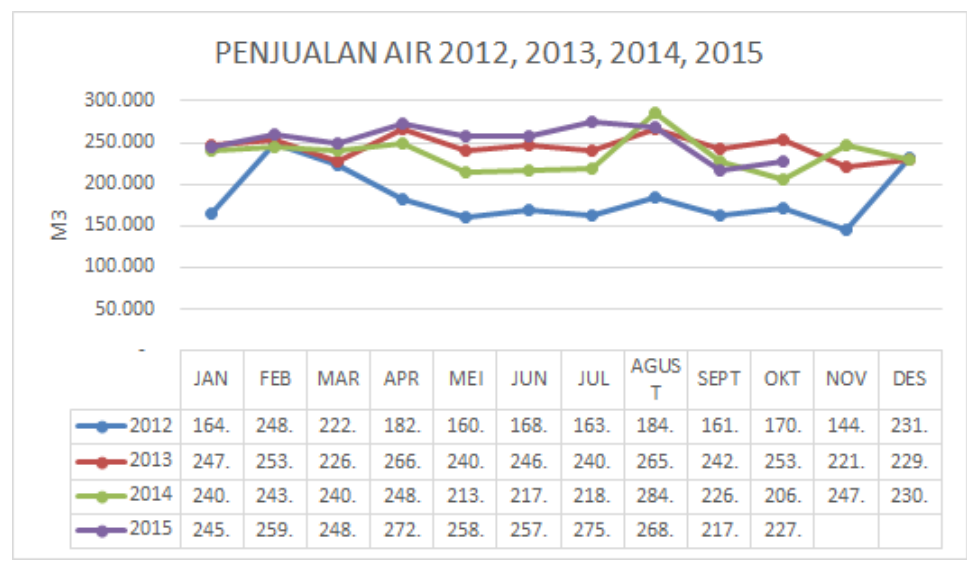

Gambar 6. Profil Penjualan Air PDAM Tirta Kepri Tahun 2012-2015

\section{Kebocoran Air}

Tingkat kebocoran air PDAM Tirta Kepri pada tahun 2015 adalah 39,31\%. Nilai ini tergolong tinggi, dimana standar kebocoran air adalah 20\%. Namun nilai kebocoran air menurun dari tahun 2012 hingga tahun 2015. Berikut adalah profil kebocoran air PDAM Tirta Kepri tahun 2012 hingga tahun 2015.

Tabel 7. Kebocoran Air PDAM Tirta Kepri Tahun 2012-2015

\begin{tabular}{|c|r|r|r|r|r|r|r|r|r|r|r|c|}
\hline NRW & JAN & FEB & MAR & APR & MEI & JUN & JUL & AGUST & SEPT & OKT & NOV & DES \\
\hline 2012 & 50,16 & 50,34 & 50,69 & 55,07 & 52,32 & 49,09 & 51,36 & 52,94 & 49,69 & 53,09 & 49,21 & 50,16 \\
\hline 2013 & 50,02 & 50,01 & 56,06 & 46,52 & 52,08 & 49,90 & 52,35 & 44,56 & 46,97 & 38,58 & 45,59 & 49,18 \\
\hline 2014 & 49,15 & 46,69 & 47,80 & 46,40 & 46,10 & 45,96 & 46,41 & 35,63 & 44,42 & 50,77 & 44,81 & 32,23 \\
\hline 2015 & 46,80 & 47,45 & 37,82 & 43,76 & 42,23 & 42,60 & 43,70 & 41,26 & 43,28 & 39,31 & & \\
\hline
\end{tabular}

Sumber: Laporan PDAM Tirta Kepri, 2016

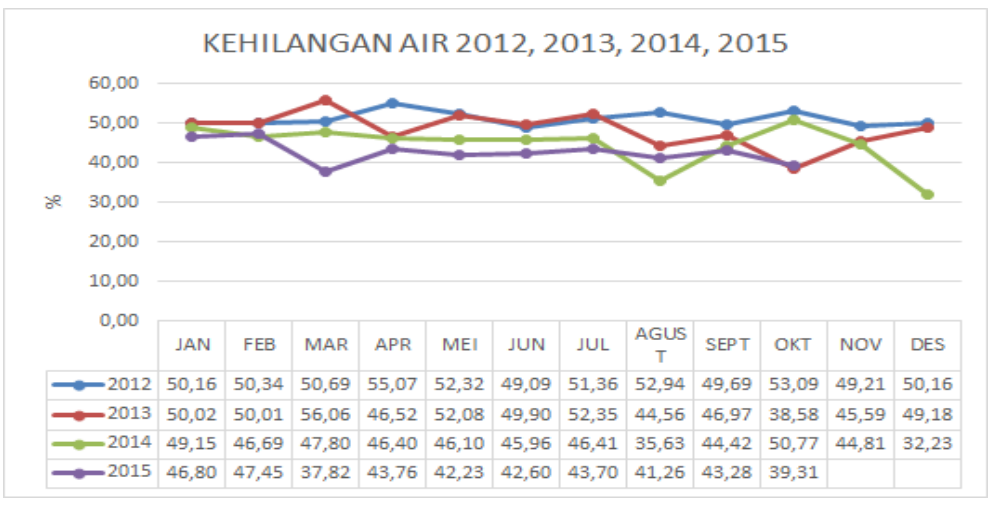

Gambar 7. Profil NRW PDAM Tirta Kepri Tahun 2012-2015

\section{Pembahasan Hasil Analisis}

Jumlah pelanggan PDAM Tirta Kepri dihitung berdasarkan jumlah sambungan rumah (SR) aktif pada tahun berjalan (BPPSPAM, 2015). Jumlah pelanggan terus meningkat dari tahun 2012 hingga tahun 2015 yang diperlihatkan pada Gambar 2. Jumlah pelanggan tahun 2015 terlihat pada Tabel 2, dimana hingga Desember 2015 sambungan rumah mencapai 15.306 SR. Hal ini mengindikasikan bahwa terjadi pertumbuhan pelanggan yang baik. Adanya pertumbuhan pelanggan merupakan salah satu ciri PDAM Sehat (BPKP, 2013), namun hasil audit BPKP tahun 2014-2015 belum terbit, sehingga tidak dapat diketahui status PDAM Tirta Kepri. 
Prosentase pelayanan PDAM Tirta Kepri dihitung berdasarkan jumlah penduduk yang terlayani dibandingkan dengan jumah penduduk total wilayah pelayanan Kota Tanjungpinang dan sebagian wilayah Kab. Bintan. Diketahui bahwa prosentase pelayanan dari tahun 2012 hingga tahun 2015 baru mencapai 30\% (Tabel dan Gambar 3). Artinya masih sekitar 70\% penduduk belum terlayani oleh PDAM Tirta Kepri. Standar pelayanan PDAM berdasarkan target pemerintah pada tahun 2019 yakni 100\% (RPJMN, 2015-2019), sehingga PDAM Tirta Kepri diarahkan untuk meningkatkan jumlah layanan.

Volume produksi air mengalami penurunan dari tahun 2012 hingga tahun 2015 dan nilai ini fluktuatif setiap bulan dan setiap tahunnya. Produksi air diolah dari air baku dengan debit yang akan berbeda pada setiap kondisi dan musim. Air baku yang digunakan oleh PDAM Tirta Kepri berasal dari Waduk Sei Pulai (Daya Cipta Mandiri, 2013). Waduk Sei Pulau mengalami penurunan debit saat musim kemarau, hal ini akan menyebabkan produksi air PDAM menurun. Penurunan debit juga akan mempengaruhi turbiditas air baku. Turbiditas yang berkisar antara 6 hingga 1400 (NTU), mengindikasikan perlunya penggunaan pre-treatment seperti pre-settling tanks terutama pada saat turbiditas tinggi (Janna \& Al-Samawi, 2014). Penurunan volume produksi air juga dapat disebabkan oleh kondisi IPA yang tidak optimal. IPA yang digunakan PDAM Tirta Kepri telah beusia puluhan tahun sehingga menyebabkan kinerja IPA tidak optimal. IPA merupakan unit produksi di PDAM. Unit produksi merupakan prasarana dan sarana yang dapat digunakan untuk mengolah air baku menjadi air minum melalui proses fisik, kimiawi, dan/atau biologi (Joko, 2010). Ketika usia IPA telah puluhan tahun, maka kinerja proses fisik, kimiawi dan biologi tidak akan optimal.

Volume distribusi air mengalami penurunan dari tahun 2012 hingga tahun 2015 dan nilai ini fluktuatif setiap bulan dan setiap tahunnya. Nilai volume distribusi lebih rendah dari volume produksi, sehingga mengakibatkan adanya kebocoran pada tingkat produk. Kebocoran ini disebut sebagai Non Revenue Water (NRW) atau air tak berekening. NRW pada tingkat produksi dapat disebabkan oleh ada kebocoran pada sistem produksi (Farley, et.al, 2008).

Volume penjualan air mengalami penurunan dari tahun 2012 hingga tahun 2015 dan nilai ini fluktuatif setiap bulan dan setiap tahunnya. Nilai penjualan ini lebih rendah dari volume distribusi air. Rendahnya nilai volume air terjual mengindikasikan adanya tingkat kebocoran pada sistem distribusi.

Kebocoran pada sistem distribusi dapat disebabkan oleh ketidakakuratan meter pelanggan, penanganan data yang buruk, dan sambungan illegal (Farley, et.al, 2008). Jika dilihat dari tingkat kebocoran air, tingkat kebocoran air PDAM Tirta Kepri pada tahun 2015 adalah 39,31\%. Nilai ini tergolong tinggi, dimana standar kebocoran air adalah 20\%. Namun nilai kebocoran air menurun dari tahun 2012 hingga tahun 2015 menunjukkan adanya perbaikan kinerja teknis PDAM Tirta Kepri, namun kebocoran perlu diminimalisir kembali hingga mencapai standar kebocoran air yakni 20\% atau kurang.

\section{Pembahasan Alternatif Rencana Tindak}

Standar pelayanan PDAM berdasarkan target pemerintah pada tahun 2019 yakni 100\% (RPJMN, 2015-2019). Sehingga PDAM Tirta Kepri perlu meningkatkan pelayanan dimana saat ini baru mencapai 30\%. Rencana tindak dalam peningkatan pelayanan PDAM Tirta Kepri meliputi peningkatan sambungan rumah, meningkatkan produksi dan distribusi air melalui optimalisasi IPA, meningkatkan penjualan air dan non air, dan menekan kebocoran.

\section{KESIMPULAN}

Berdasarkan hasil evaluasi kinerja teknis pelayanan PDAM Tirta Kepri Kota Tanjungpinang tahun 2012-2015 diketahui bahwa jumlah pelanggan mengalami peningkatan dari tahun 2012 hingga tahun 2015, dimana jumlah pelanggan tahun 2012 sebesar 14.769 SR meningkat pada tahun 2015 mencapai 15.306 SR. Prosentase pelayanan dari tahun 2012 hingga tahun 2015 baru mencapai 30\%, belum memenuhi target pemerintah. Volume produksi air mengalami penurunan dari tahun 2012 hingga tahun 2015 dan nilai ini fluktuatif setiap bulan dan setiap tahunnya, dimana pada Desember 2012 volume produksi mencapai $473.108 \mathrm{~m}^{3}$ menurun pada Oktober 2015 menjadi $385.865 \mathrm{~m}^{3}$. Volume distribusi air mengalami penurunan dari tahun 2012 hingga tahun 2015 dan nilai ini fluktuatif setiap bulan dan setiap tahunnya. Nilai volume distribusi lebih rendah dari volume produksi. Volume penjualan air mengalami penurunan dari tahun 2012 hingga tahun 2015 dan nilai ini fluktuatif setiap bulan dan setiap tahunnya. Nilai penjualan ini lebih rendah dari volume distribusi air. Sedangkan tingkat kebocoran air mengalami peningkatan kinerja pada tahun 2015 mencapai 39,31\%. Rencana tindak dalam peningkatan pelayanan PDAM Tirta Kepri meliputi peningkatan sambungan rumah, meningkatkan produksi dan distribusi air melalui optimalisasi IPA, meningkatkan penjualan air dan non air, dan menekan kebocoran. 


\section{DAFTAR PUSTAKA}

BPKP, 2012-2014, Buku Evaluasi Kinerja PDAM Tirta Kepri, Badan Pengawasan Keuangan dan Pembangunan, Jakarta.

BPPSPAM, 2015, Buku Kinerja PDAM, Badan Pendukung Pengembangan Sistem Penyediaan Air Minum, Kementerian Pekerjaan Umum dan Perumahan Rakyat, Jakarta.

Daya Cipta Mandiri, CV, 2013, RISPAM Kota Tanjungpinang, Konsultan CV. Daya Cipta Mandiri, Cimahi.

Farley, M., Wyeth, G., Ghazali, Z., Istandar, A., \& Singh, S., 2008, Buku Pegangan tentang Air Tak Berekening (NRW) untuk Manajer form orginal book The Manager's Non-Revenue Water Hanbook: A Guide to Understanding Water Losses, Direktorat Jendela Cipta Karya, Kementerian Pekerjaan Umum dan Perumahan Rakyat, Jakarta.

Janna, H. \& Al-Samawi, A.A., 2014, Performance Evaluation of Al- Karkh Water Treatment Plant in the City of Baghdad, RESEARCH ARTICLE, International Journal of Advanced Research, Volume 2, Issue 10, 823-829. Joko, T., 2010, Unit Produksi dalam Sistem Penyediaan Air Minum, Graha Ilmu, Jakarta.

Kaplan, Robert S \& David P Norton (Peter R Yosi Pasla, Penerjemah), 2000, Balanced Scorecard: Menerapkan Strategi Menjadi Aksi, Erlangga, Jakarta.

PDAM Tirta Kepri, 2016, Laporan Teknik PDAM Tirta Kepri, PDAM Tirta Kepri, Tanjungpinang.

Peraturan Pemerintah RI No. 122, 2015, Sistem Penyediaan Air Minum, Download dari www.hukumonline.com.

RPJMN, 2015-2019, Pembangunan Jangka Menengah Nasional (RPJMN), Direktorat Jenderal Cipta Karya, Kementerian Pekerjaan Umum dan Perumahan Rakyat, Jakarta. 